\title{
PERSUASIÓN Y MITO EN LOS ORÍGENES DEL DRAMA SÁNSCRITO. A PROPÓSITO DEL PRIMER LIBRO DEL NĀTYYÁSATSTR**
}

\author{
Óscar Figueroa Castro \\ Universidad Nacional Autónoma de México \\ figueroa@correo.crim.unam.mx
}

\section{PERSUASION AND MYTH IN THE ORIGINS OF SANSKRIT DRAMA. APROPOS OF NATTYYÁSÁSTRA'S FIRST BOOK}

\begin{abstract}
RESUMEN: La reflexión sobre los orígenes del drama sánscrito ha girado alrededor de dos tesis: por un lado, un origen védico-ritual; por el otro, un origen al margen del ritualismo brahmánico. A la luz de dicha controversia, el artículo revisa el mito sobre el origen del teatro en el primer capítulo del Nātyaśāstra (aprox. siglos II-IV d. C.) y estudia la compleja idea de origen articulada en este testimonio tardío, la cual descansa en un intercambio de premisas védicas y no védicas, religiosas y puramente teatrales, insertas en una retórica fundacional y, justamente por ello, con una clara conciencia de la necesidad de retener un halo arcaico.
\end{abstract}

PALABRAS CLAVE: Teatro sánscrito, Nātyaaśāstra, teatro y religión, persuasión y mito.

\begin{abstract}
The study about the origins of Sanskrit drama has revolved around two positions: on the one hand, a Vedic-ritual origin; on the other, an origin outside Brahmanical ritualism. In the light of such controversy, this paper studies the myth about the origins of drama in the first chapter of the Nātyaśāstra (ca. II-IV A. D.), and explores the complex idea of origin articulated in this late testimony. This rests upon an interplay of Vedic and non-Vedic, religious and purely theatrical presuppositions, both inserted within a seminal rhetoric, which, for that very reason, exhibits a deep awareness about the importance of preserving an archaic aura.
\end{abstract}

KEYWORDS: Sanskrit drama, Nātyaśāstra, Theatre and Religion, Persuasion and Myth.

RECIBIDO: 10.06.2013. ACEPTADO: 25.03.2014

* Como complemento indispensable a la lectura de este artículo, en la revista Nova Tellus (México, Instituto de Investigaciones Filológicas, 32-1, 2014) publiqué una traducción íntegra del primer libro del Nātyaśāstra, hasta donde sé la primera al castellano a partir del original sánscrito. Cabe notar que recientemente apareció en español el texto completo (Valencia, Letra Capital, 2013), pero se trata de una traducción realizada, aparentemente, a partir de una versión inglesa. Agradezco al revisor anónimo que llamó mi atención sobre la misma, notando sus limitaciones. 


\section{Preámbulo: el controversial origen del dRAma SÁNSCRito}

Desde los inicios de la indología como disciplina académica, durante la segunda mitad del siglo XIX, el estudio del teatro sánscrito se ha caracterizado por articular y defender lo que podríamos llamar la tesis del origen védico. Ésta no ha perdido su vigencia y, sustentada en diversos esfuerzos explicativos y genealogías, en varios casos prevalece ${ }^{1}$, desestimando los esfuerzos de quienes han intentado defender un origen popular o al margen de la cultura védica ${ }^{2}$.

Como puede adivinarse, la implicación más obvia de dicha prevalencia es un origen religioso y, más exactamente, ritual para el drama sánscrito. Entre las evidencias más socorridas al respecto se encuentra la secuencia de ritos que aparecen prescritos a manera de preámbulo (pūrvarañga) en los primeros cinco libros del tratado canónico sobre la materia, el Nātyaśāstra, cuya redacción ha sido fechada hacia los siglos II-IV de nuestra era ${ }^{3}$. Un tanto paradójica resulta, sin embargo, la escasa atención que ha recibido el primero de esos capítulos preliminares, dedicado precisamente a los orígenes del teatro (nātyopatti), sobre todo porque el mismo despliega una retórica que bien puede interpretarse a favor de la tesis védica. Aparentemente, el capítulo ha desalentado a más de un especialista porque, envuelto en un halo de mito y leyenda, su hilo

${ }^{1}$ Los diferentes argumentos a favor de la tesis védica aparecen recogidos en un par de obras de finales del siglo pasado: F. B. J. Kuiper, Varuṇa and Vidūṣaka. On the Origin of the Sanskrit Drama (Amsterdam - Oxford - New York 1979) y M. K. Byrski, Concept of Ancient Indian Theater (Delhi 1974). En varios sentidos, las sospechas de un origen védico en autores clásicos como S. Lévi (Le théâtre indien [Paris 1890]), A. B. Keith (The Sanskrit Drama [Oxford 1924]) y P. Thieme (Das indische Theater [Stuttgart 1966]), entre muchos otros, aparecen cristalizadas en este par de estudios capitales, cuyo argumento puede reducirse al silogismo nātya es yajña, el teatro es sacrificio.

${ }^{2}$ Son varias las líneas de investigación que al respecto se han propuesto. Destaca la recitación "teatralizada" de los relatos épicos, lo que supondría el acompañamiento de movimientos dancísticos, gesticulaciones y música. Por su parte, los cultos a deidades populares como Kṛṣna y Śiva a menudo también involucraban no sólo música y danza, sino asimismo pantomima y mímica. Algunos especialistas han prestado atención a un posible origen en el juego de marionetas y el teatro de sombras; otros han insistido en volver la mirada al teatro prácrito. Para un resumen de estas alternativas con referencias bibliográficas véase L. Renou, La recherche sur le théâtre indien depuis 1890 (Paris 1963) y más recientemente Kuiper, op. cit. 100-117.

${ }^{3}$ Nātyaśāstra 5.7: “Oh eminentes sacerdotes, se llama pūrvarainga porque su representación tiene lugar sobre el escenario (rañga) antes (pürvam) [de la puesta en escena propiamente]" (yasmād rañge prayogo yam pūrvam eva prayujyate tasmād ayam pūrvarañgo vijñeyo dvijasattamāh). Uso en todos los casos la edición de Baroda (Gaekwad Oriental Series). Por mucho tiempo se creyó que el texto era más antiguo. Como sea, las estimaciones siguen evidenciando un rango de variación de dos a tres siglos, en buena medida porque, al igual que muchos otros textos sánscritos, lejos de ser una obra autoral el Nâtyaśāstra es el resultado de varias generaciones de redactores y compiladores. Al respecto, los especialistas parecen coincidir en dos cosas: por un lado, es probable que las porciones más antiguas hayan sido redactadas en los primeros años de la era común o quizá antes; por el otro, definitivamente el texto -o una versión del mismo- es anterior al poeta y dramaturgo Kālidāsa (segunda mitad del siglo IV), pues éste reconoce su autoridad en los dramas Mālavikāgnimitra (1.15 y siguientes) y Vikramorvaśi (2.18). Para un resumen de los diferentes esfuerzos para fechar el texto, véase Kuiper, 119, n. 44. 
narrativo resulta impenetrable al escrutinio científico y dificulta la obtención de datos duros ${ }^{4}$.

El libro de F. B. J. Kuiper representa una saludable excepción y así, tomándose muy en serio los elementos míticos en el capítulo, intenta reconstruir la dimensión ritual del teatro sánscrito y, en última instancia, dar a la tesis del origen védico-brahmánico un valor absoluto:

Un análisis del primer capítulo del Nātyaśāstra permite concluir que el drama [...] tuvo un carácter religioso [...] Por donde se vea, el hecho de que el arte dramático haya recibido el título de "quinto Veda" demuestra que fue visto como algo que pertenece al ámbito de la religión y no al del entretenimiento 5 .

El problema con tan categórica defensa de la tesis védica es que, trasladada al horizonte cultural de los primeros siglos de la era común, no le hace justicia ya no únicamente a la trama de la gran mayoría de los dramas sánscritos -los cuales evidencian un interés más bien trasnochado y convencional por la cultura védica- sino asimismo a pasajes clave dentro de este primer libro del Nātyaśāstra, los cuales parecen apuntar en una dirección distinta, aunque no necesariamente excluyendo o negando el legado védico, o, quizá más exactamente, el prestigio que ese legado puede irradiar sobre el arte teatral.

Consciente de esta tensión, no hace mucho D. L. Gitomer puso en entredicho el valor absoluto de la tesis védica y en un breve artículo ${ }^{6}$, basado también en los primeros capítulos del Nātyaśāstra, delineó algunas ideas básicas de camino a una reivindicación de las aspiraciones propiamente estéticas y escénicas del drama sánscrito, en particular a la luz de su profundo vínculo con la tradición épica (itihāsa). Publicado casi al mismo tiempo, el monumental estudio de L. Bansat-Boudon, Poétique du théâtre indien, posee a su manera implicaciones similares y así insiste en que, más allá de su innegable filiación con el horizonte sacrificial brahmánico, el preámbulo mítico-ritual del Nātyaśāstra "participa incluso más del teatro mismo" y, "lejos de ser una mera reiteración" conmemorativa, "en realidad aspira a fundar la teatralidad del acontecimiento por venir", esto es, la puesta en escena como tal'

A la luz de esta controversia ofrezco a continuación un análisis interpretativo del primer capítulo del Nātyaśāstra. Mi reflexión pone de relieve la riqueza de

\footnotetext{
${ }^{4}$ Véase Lévi, op. cit. 299 y S. K. De, "The Origins and Characteristics of the Drama", en S. Dasgupta (ed.), A History of Sanskrit Literature I (Calcuta 1947) 43.

${ }^{5}$ Kuiper, op. cit. 121-122; también 129, 142.

${ }^{6}$ A saber, "Whither the Thick Sweetnes of their Passion? The Search for Vedic Origins of Sanskrit Drama", en L. L. Patton (ed.), Authority, Anxiety, and Canon. Essays in Vedic Interpretation (New York 1994).

${ }^{7}$ Poétique du théâtre indien. Lectures du Nātyaśāstra (Paris 1992) 70, 79.
} 
tradiciones que recorre dicho capítulo y, al mismo tiempo, hace particular hincapié en su textura retórico-persuasiva, de la que, como se verá, forma parte la narración mítica. Tal aspecto no sólo no ha recibido la atención que merece; en mi opinión puede además enriquecer el debate sobre los orígenes del drama sánscrito, al menos en lo que concierne a la tardía, pero normativa, perspectiva del Nātyaśāstra. En este caso, lo que al parecer está en juego es una idea más compleja de origen, la cual descansaría sobre un intercambio de premisas védicas y no védicas insertas en una estrategia discursiva seminal, fundacional, y, justamente por ello, con una clara conciencia de la necesidad de retener un halo arcaico y sagrado.

\section{LA HISTORIA RESUMIDA}

El primer capítulo del Nātyaśāstra comprende varios relatos que guardan entre sí una relación conforme al modelo tradicional de una historia dentro de otra. Como sabemos, este patrón narrativo se repite en otros especímenes de la literatura sánscrita, en especial en la épica y la fábula, lo que de entrada establece cierta afinidad. Entonces, un narrador anónimo cuenta cómo un grupo de ascetas se acerca al sabio Bharata a fin de conocer los orígenes del teatro (estrofas 1-5). El legendario sabio accede a relatar los pormenores (6-7). El recuento incluye la secuencia de causas y eventos que desembocaron en la invención del teatro, así como en la primera puesta en escena. Se aduce una causa de orden moral-aquí y allá se asoman los primeros síntomas de degradación social, consecuencia directa del inexorable paso del tiempo, y es necesario aleccionar a las clases más bajas-, mas ésta viene precedida de un motivo puramente estético -la necesidad de crear un pasatiempo-. La solución: un quinto Veda, el Teatro mismo, que satisfaga ambas demandas (8-12). El dios creador Brahmā se encarga de darle forma; toca a alguien más ponerlo en práctica (estrofas 13-20). Alegando incompetencia, Indra y el resto de los dioses declinan la oferta de Bhramā de convertirse en artífices y, en cambio, proponen al sabio Bharata (21-23), quien, con el apoyo de sus hijos, lo estudia y codifica (24-42). Tras un tiempo, el sabio pone a Brahmā al tanto de sus progresos y éste le pide que implemente el estilo kaisíikì, y con ese fin le otorga ninfas, músicos y cantantes (43-52). El proceso de codificación del quinto Veda está completo. El anuncio coincide con el inicio de la fiesta que conmemora la victoria mítica de Indra sobre los demonios. El dios Brahmā no duda en recomendar la festividad como la ocasión ideal para llevar el nuevo Veda al escenario (52-55). Bharata decide poner en escena los mismos sucesos que celebra la fiesta. Los espectadores son dioses y demonios. Complacidos, los primeros otorgan un sinfín de dones (55-63). Ofendidos, los segundos dan vida a una serie de "obstáculos" (vighna) a fin de boicotear el espectáculo (63-66). Indra se percata del problema y usando como arma su estandarte destruye a los demonios inconformes (66-75). Nuevos demonios amenazan con arruinar el espectáculo. 
Bharata le pide a Brahmā una solución y éste encarga a Viśvakarmā la construcción de un recinto y luego asigna el cuidado de cada una de sus áreas a diferentes deidades y criaturas divinas (75-98). Al parecer el remedio es insuficiente, pues los dioses acuden a Brahmā y le ruegan que alcance un acuerdo pacífico con los demonios. Cuestionados, éstos se quejan de que el teatro los ridiculiza y exigen un trato justo (99-104). Brahmā responde con un largo discurso sobre el espíritu universal del teatro, definido precisamente como un arte mimético que busca reflejar todos los aspectos de la existencia (105-124). Por último, ordena la ejecución de una serie de ritos sobre el escenario, anticipando así el contenido de los siguientes capítulos (125-131).

Este rápido recuento del contenido del capítulo pone de manifiesto una innegable presencia de elementos cosmogónicos de ascendencia védica. En particular, y gracias al estudio de Kuiper, hoy sabemos que lo que subyace a esta entretenida trama es la memoria del episodio mítico por el que Indra dividió el cielo y la tierra usando un pilar cósmico (yașți), verdadero axis mundi ${ }^{8}$. De hecho, el estandarte (dhvaja) que Indra usa como arma (jarjara) para atacar a los demonios es un símbolo del pilar cósmico con el que vence al caos e instaura el orden.

Entonces, de acuerdo con esta interpretación normativa, el teatro mantiene un estrecho vínculo y, más aún, se confunde con esta imagen mítica de la creación, la misma que en primera instancia actualiza la memoria ritual y festiva. En este sentido no es incorrecto afirmar que teatro y rito recrean, cada uno sobre su propio escenario y con recursos diferentes, un mismo acontecimiento9. Empero existe una jerarquía: indiscernible de su profundo trasfondo mítico, el rito per se precede al rito teatralizado. Entonces, mientras que la fiesta del estandarte habría tenido como principal objetivo recordar anualmente ${ }^{10}$ la unidad restaurada del cosmos o, en términos míticos, la victoria de los dioses sobre las hordas de demonios, los ritos que el Nātyaśástra prescribe como preámbulo representarían una segunda reiteración o réplica del mismo evento con base en el concepto de imitación (anukarana) ${ }^{11}$.

Ahora bien, para Kuiper la precedencia del rito per se acaba funcionando como premisa metodológica: el origen del teatro es comprensible únicamente a la

\footnotetext{
${ }^{8}$ Antes de Kuiper, J. Gonda definió el festival en general como "un ritual regio a beneficio del emperador y su supremacía militar". Véase "The Indra Festival According to the Atharvavedins", Journal of the American Oriental Society 87-4 (1967) 414.

${ }^{9}$ Por ejemplo, en el libro quinto leemos que, como parte también de los ritos preliminares, el director debe portar el estandarte de Indra mientras recita algunos versos y ejecuta complejos movimientos dancísticos para propiciar a los dioses y ahuyentar cualquier infortunio.

${ }^{10}$ De hecho tenía lugar durante el solsticio de invierno, al comienzo del nuevo año. Véase Kuiper, op. cit. 133-141.

${ }^{11}$ Véase Kuiper, op. cit. 195. Cabe señalar que esta segunda réplica comprende a su vez dos momentos: primero, los actores que dan vida a dioses y demonios pelean sobre el escenario; luego son dioses y demonios quienes pelean. Esta secuencia permite actualizar de una manera un tanto inesperada el desenlace del mito original. Volveré a ello más adelante.
} 
luz de su prototipo, en relación con ese pasado que reitera, de modo que si el dios Brahmā proclama que el teatro es "comparable al sacrificio" (1.128: yajñasammita) es porque, en efecto, originalmente el teatro era sólo sacrificio, y si después dejó de serlo -por ejemplo en la obra de los grandes dramaturgos sánscritos-, fue porque experimentó un simple y natural proceso de secularización ${ }^{12}$.

Me parece que es posible y necesario matizar esta postura, pues la misma corre el riesgo de caer en un reduccionismo que ve en la representación teatral (o para tal caso en el rito teatralizado) un simple medio al servicio del gran pasado védico, sin detenerse en las implicaciones de esta duplicidad y obviando otro tipo de indicios presentes en el propio relato del Nātyaśāstra, omisión que puede hacernos pensar, erróneamente, que el texto es un testimonio directo de los orígenes del teatro sánscrito y no una apropiación interpretativa posterior. $\mathrm{Al}$ respecto pueden plantearse varias preguntas. ¿A quién beneficia la reiteración del mito a través del teatro? ¿A la tradición sacerdotal, a la teatral? ¿Cabe pensar que dicha reiteración es premeditada, que forma parte de una estrategia discursiva encaminada a trascender el mero afán de dar continuidad al legado sacrificial brahmánico? ¿Nos conduce el relato mítico de Indra y su puesta en escena exclusivamente al pasado, al modelo védico, tenido como su verdadera y única fuente? ¿Cabría en cambio, como insiste L. Bansat-Boudon, repensar las preocupaciones de los primeros libros del Nātyaśāstra a la luz del inédito espectáculo que los mismos anuncian y, por lo tanto, con una mayor sensibilidad al periodo en que se redactó el texto? ¿Es pertinente pensar que la reiteración ritual y escénica del pasado védico acaba instaurando un nuevo orden, estableciendo los fundamentos de una visión distinta de la realidad? ¿Se reduce el teatro a imitar el rito y por ello mismo es rito también? ¿Nada hay de por medio -ningún valor agregado-; nada se pone en juego en este proceso? Si así fuera, ¿qué llevó entonces a organizar y codificar la actividad de actores, bailarines y músicos? El continuum original de rito y mito habría bastado. Sin embargo, no fue así porque en efecto emergió una nueva tradición, la tradición teatral.

Desde luego, estas sospechas se fortalecen a medida que uno avanza en la lectura del Nātyaśástra y los elementos rituales de los primeros cinco libros comienzan a desdibujarse cediendo el paso a un profuso catálogo de preocupaciones estéticas y técnicas que, si bien mantienen el marco narrativo del primer libro, parecen alejarse de la mera necesidad de remitir su origen y aspiraciones a la autoridad ritual brahmánica ${ }^{13}$.

\footnotetext{
${ }^{12}$ Kuiper, op. cit. 159.

${ }^{13}$ Lo que ha llevado a más de uno a conjeturar que el verdadero inicio del tratado estaría en el capítulo sexto, mientras que los primeros cinco capítulos serían una adición posterior con fines apologéticos. Al respecto véase P. V. Kane, History of Sanskrit Poetics (Delhi 1971) 16-20.
} 


\section{La (PERSuAsiva) ESTATURA VÉDicA DEL teAtro}

En tanto śāstra, el Tratado sobre teatro o la Ciencia del teatro, los dos posibles sentidos del título Nâtya-śāstra, posee un estilo al mismo tiempo descriptivo y normativo, contribuyendo así, como lo hiciera Pāṇini con la lengua sánscrita, a depurar y fijar las reglas que subyacen a un arte que, por su magnitud y riqueza, parecía estar destinado a desafiar cualquier intento de codificación.

Sin embargo, desde sus primeras líneas el texto introduce una nomenclatura distinta. El conocimiento que el Nātya-śāstra expone tiene su fundamento en cierto Nătya-veda ${ }^{14}$. Concebido como Veda, esto es, como palabra revelada, en realidad el Nâtyaveda precede al Nätyaśāstra, su expresión sistematizada y, hasta cierto punto, secular ${ }^{15}$. De hecho, el compuesto Nätya-veda es acuñado con la pretensión de emular el nombre de los cuatros Vedas tradicionales, de modo que la palabra nătya, "teatro", funciona como nombre propio ${ }^{16}$.

En la misma dirección se inscriben tanto el epíteto "quinto Veda" (pañcamaveda), por sí sola una etiqueta con tradición y prestigio ${ }^{17}$, como la reiterada comparación con los cuatro Vedas originales (estrofa 4) ${ }^{18}$, el $R g$, Sāma, Yajur y Atharva Vedas, de los que de hecho deriva sus distintos componentes (estrofa 17). El paralelo comprende asimismo el proceso de transmisión del texto desde el plano divino al de los mortales. Entonces, el muni ("sabio") Bharata es elevado a la legendaria categoría de rși ("profeta") al servir como receptáculo y transmisor de la revelación (estrofa 23). Además, como todo Veda, el Teatro exige la asistencia de ciencias auxiliares (vedāinga) que diseminen y esclarezcan su mensaje (estrofa 5).

${ }^{14}$ Cabe notar que Abhinavagupta, el gran exegeta del siglo X autor de un brillante comentario al Nātyaśāstra, en ocasiones se refiere a este texto por el título de Nātyaveda. Véase por ejemplo Íśvarapratyabhijñāvivṛtivimarśin̄̄, vol. 2, 179: "He abundado sobre la materia en mi Abhinavabhāratī, extenso comentario al Veda-Teatro" (ayam artho 'bhinavabhāratyām nātyavedavivrtau vitatya vyutpādito 'smabhir iti).

${ }^{15}$ Aunque no por ello menos canónica. En efecto, muy a menudo la categoría de śāstra fue también utilizada con el fin de investir con un halo de autoridad atemporal los contenidos de los más diversos textos. Al respecto véase Sh. Pollock, "The Theory of Practice and the Practice of Theory in Indian Intellectual History", Journal of the American Oriental Society 105-3 (1985) 499-519.

${ }^{16}$ Como explican Kuiper (op. cit. 121) y Bansat-Boudon (op. cit. 25), el compuesto es descriptivo (karmadhāraya) y, por lo tanto, antes que designar al Veda que tiene por objeto el teatro, en realidad se trata del Veda que es el Teatro. El propio texto sugiere este sentido en 1.20 y 1.55: este Veda "llamado Teatro" (nātya-saṃjña).

${ }^{17}$ La expresión data de las Upaniṣads. Piénsese en el famoso pasaje de la Chāndogya (7.1.2-4) donde el neófito Nārada enuncia los múltiples conocimientos que ha adquirido, todos ellos, para decepción de su maestro, "puramente nominales". Éstos incluyen en primer término la lista tradicional de cuatro Vedas, a la que se suma un quinto Veda, el corpus de "leyendas y antiguos relatos" (itihāsapurānam). Véase asimismo Bṛhadāranyaka 2.4.10, 4.1.2 y 5.5.11. Después de las Upaniṣads quizá el testimonio mejor conocido sea el del Mahābhārata, definido precisamente como el quinto Veda (por ejemplo en 1.1.205; 1.2.235 y siguientes).

${ }^{18}$ 1.4: vedasammita, "comparable a los Vedas", es un epíteto común para el corpus de leyendas (itihāsa) y antiguos relatos (purāṇa). Así, por ejemplo, en Mahābhārata 12.326.106 y siguientes. 
¿Qué razones aduce el propio Nātyaśāstra para justificar esta búsqueda de identificación con la tradición revelada? Dejando de lado momentáneamente el trasfondo ritual de dicha búsqueda, la primera respuesta que el texto ofrece aparece articulada también en clave ortodoxa, en este caso de orden didáctico. El Teatro es Veda o debe serlo porque su fin es educar o, más exactamente, normar la conducta de aquellos que, de acuerdo con la perspectiva elitista brahmánica, ponen en riesgo la estabilidad social y cósmica al entregarse a "prácticas obscenas" (estrofa 9). Ahora bien, lo que aparenta ser una empresa noble posee sin embargo una arista derogatoria. Los primeros signos de degradación moral y social tienen un culpable: "las mujeres, las clases bajas y demás" (estrofa 14) grupos al margen del monopolio religioso védico. La tarea es delicada. De un lado, como es bien sabido, los Vedas sólo pueden ser estudiados por los miembros masculinos de las tres clases superiores, los dvija o "nacidos dos veces", así llamados en virtud de contar con un nacimiento biológico y uno "religioso", este último el que les confiere la iniciación; del otro, resulta apremiante contrarrestar el proceso de degradación inculcando en la población marginada los valores esenciales de la sociedad brahmánica. Así las cosas, propagar el mensaje védico más allá de los confines de la tradición sin poner en riesgo la pureza e integridad de esa tradición sólo puede lograrse a través de la creación de un quinto Veda, al mismo tiempo profano -al alcance de las masas-y sagrado -investido con la autoridad atemporal, al margen de la historia, de los Vedas originales-.

Como vimos, la retórica hasta aquí delineada se nutre de un proceso paralelo de homologación por el que el teatro es retratado como la escenificación de un antiguo rito y, en ese sentido, como su reiteración: el "quinto Veda es comparable al sacrificio", declara el capítulo casi al final.

Una primera conclusión resulta evidente: hay una necesidad de obtener credibilidad, legitimidad, y con ese fin el texto recurre a los Vedas, la fuente por antonomasia de autoridad y estatus ${ }^{19}$, echando mano de diversos registros discursivos, todos ellos enmarcados en un relato mítico-ritual. Ahora bien, si una primera lectura del texto hace tangible la omnipresencia del elemento védico como fuente de autoridad y posible origen del teatro, al revisar con más detenimiento la retórica empleada -tenaz, a veces incluso redundante en su ánimo persuasivo- es claro que se trata más de una aspiración que de un hecho ${ }^{20}$. Se insiste de tal manera en la estatura védica del teatro que uno comienza a dudar del carácter definitivo de dicho alegato.

${ }^{19}$ De hecho, el texto apela de manera secundaria a otras fuentes de autoridad, por ejemplo las tradiciones ascética (estrofas 2-3), yóguica (117), política (98-100) e incluso la filosófica (5). Por razones de espacio no me es posible aquí revisar cada una.

${ }^{20}$ Como indicio puede mencionarse la importancia otorgada al acto de recordar los Vedas originales (estrofas 13 y 16), de modo que a pesar del espíritu comparativo y aun identitario que sugiere el título "quinto Veda", lo cierto es que el teatro no se revela espontáneamente, no es śruti, mensaje primordial acogido por el oído atento del profeta; es en cambio memoria (smṛti). 
De este primer diagnóstico se desprenden dos alternativas: para la época del Nātyaśástra, el teatro sánscrito fue concebido como un evento que emerge desde su pasado védico con pretensiones de autonomía y, por ello mismo, necesita el consentimiento y la autoridad que sólo puede otorgarle su privilegiada ascendencia; o, por el contrario, como una tradición en la que se agitan inquietudes de un orden distinto, aunque no ajenas a la corriente dominante de la antigua cultura sánscrita con su marcada tendencia al elitismo y el conservadurismo, y por ello mismo, el horizonte védico representa el referente lógico. Ambas opciones sugieren que la necesidad de confirmar la vigencia de la cosmovisión védica a través de una retórica arcaizante que tiene en el mito su mejor aliado no opera únicamente hacia ese pasado canónico. ¿Forma parte de una estrategia retórica más amplia el discurso pro-brahmánico que legitima la creación de un quinto Veda? ¿Desea persuadirnos de algo más que la simple ascendencia ortodoxa del teatro?

\section{LA DIMENSIÓN LÚDICA DEL TEATRO}

Las cosas no son tan simples como parecen. De entrada cabe recordar que la encomienda didáctica, luego encauzada a través del mito y el ritual, viene antecedida en el propio texto por un propósito en apariencia secundario: divertir, entretener. De voz de Indra, el teatro es un "juguete", un "pasatiempo"21, y como tal, confirma Brahmā en su exhortación final, "trae alegría, esparcimiento y dicha", $y$ en todas partes es una "fuente de gozo"22.

Como puede sospecharse, la tesis del origen védico tiene dificultades para reconocer un objetivo lúdico, ajeno a la solemnidad y la formalidad del ritual. No sorprende entonces que en su libro Kuiper minimice y casi obvie su presencia ${ }^{23}$. Empero, el texto indica lo contrario y así, usando a su favor la división de castas y las restricciones que dicho sistema impone, nos recordará que los dos fines asignados al teatro, instrucción y gozo (vyutpatti y rasa), no son indisociables; es posible apelar al primero - confirmando con ello la autoridad de la tradición védica- sin renunciar al segundo - evocando entonces cierta limitación al interior de dicha tradición-. Como señala L. Bansat-Boudon: "A este Veda [...] no se accede por la vía normal, la de la iniciación y el estudio -larga, austera, sagrada y reservada a los dvijas-: en cierto sentido, este nuevo Veda es un Veda sustituto que debe instruir al divertir" ${ }^{\prime 24}$.

Entonces, la preocupación por las implicaciones cósmicas que pueda tener la moral relajada de la población al margen de los elitistas valores brahmánicos, la misma preocupación que empuja a Indra a buscar generalizar el conocimiento

\footnotetext{
${ }^{21}$ 1.11: krīụanīyakam.

${ }^{22}$ Respectivamente 1.113 y 1.123: dhritikrī d̄asukhādikṛt y vinodajanana.

${ }^{23}$ Kuiper, op. cit. 122, n. 52, y 126.

${ }^{24}$ Bansat-Boudon, op. cit. 57.
} 
con la ayuda de Brahmā, acaba sugiriendo, entre líneas y sin contradecir la hegemonía védica, una potencial subordinación del saber al placer. Esta convergencia de ideales cuyo latente antagonismo es disimulado a través de una retórica de integración, aparece también en la manera como el texto apela constantemente no sólo a la autoridad de los Vedas sino a la de un segundo cuerpo textual, el de las antiguas leyendas y relatos (itihāsa).

Como apenas vimos, legitimar el teatro supuso para los redactores del Nātyaśāstra crear un paralelo entre este arte y los Vedas, de modo que aquél alcanzará la estatura de éstos, pero sin poner en riesgo su pureza. El uso retórico de la etiqueta "quinto Veda" busca persuadir al lector justo de eso y lo logra porque la tradición ha canonizado dicha etiqueta en esa misma función. Es significativo, sin embargo, que la historia textual registré el uso de dicho epíteto para el cuerpo de leyendas, mitos y relatos antiguos englobados bajo la categoría itihāsa ${ }^{25}$. Más significativo todavía es que dicha categoría aparezca asociada en nuestro texto con la creación del Nātyaveda, como si, una vez concebido como quinto Veda, fuera casi imposible no asociarlo también con esta otra fuente de autoridad. Entonces, cuando el dios Brahmā hace expresa su voluntad de crear el Nātyaveda, hará la precisión, en apariencia innecesaria y hasta impropia, de que este nuevo Veda "contiene leyendas"26. La aposición de este par de categorías, revelación (veda) y relato mítico (itihāsa), reaparece unos versos más adelante en un tono incluso más categórico, de identidad. Así, habiendo creado el Veda-Teatro, Brahmā informa a Indra: "Yo creé esta leyenda; toca ahora a los dioses llevarla a la práctica" ${ }^{27}$. El Nātya-Veda en su conjunto es ahora calificado como itihāsa. Por último, esta identidad experimenta un súbito giro a favor de itihāsa hacia el final del capítulo, completando esta retórica de doble filo. Entonces, leemos que, al inspirarse en veda e itihāsa, el "teatro será una fuente de alegría para toda la gente" 28 . Al recordarnos que el propósito fundamental del teatro es divertir (vinoda) y a sabiendas de que los Vedas tradicionales no persiguen dicho fin, de manera indirecta esta aseveración introduce una jerarquía entre las dos fuentes del teatro, subordinando los valores religiosos y rituales a los literarios y estéticos. La búsqueda de legitimidad parece haberse extendido a otras potestades; el teatro no sólo reconoce y adula la autoridad de los Vedas. Algo más está de por medio.

\footnotetext{
${ }^{25}$ Véase antes n. 18; también Gitomer, pp. 84-85. Junto con ākhyāna ("narración”), la categoría suele asociarse de manera rutinaria con el Mahābhārata. En nuestro caso aquí, sin embargo, la misma tiene un sentido más amplio y designa cualquier tipo de relato legendario o mítico, lo que coincide, en los hechos, con los temas tratados por los grandes dramaturgos sánscritos desde Bhāsa hasta Bhavabhūti.

${ }^{26} 1.15 \mathrm{~cd}$ : “Doy forma, pues, al quinto Veda, el Veda llamado Teatro, el cual contiene leyendas" (nātyākhyam pañcamam vedam setihāsaṃ karomy aham).

${ }^{27}$ 1.19cd: itihāso mayā ș̣̦țaḥ sa sureșu niyujyatām. Al parecer, la idea es que la materia prima del teatro son las leyendas y los relatos míticos que llevados al escenario dan plena identidad al género dramático. Desde luego, esto sugiere que el antiguo quehacer narrativo sánscrito posee fuertes componentes escénicos: los mitos y leyendas son obras de teatro en potencia, lo que confirma, una vez más, una verdad histórica.

${ }^{28} 1.122 \mathrm{~cd}$ : vinodakaraṇam loke nātyam etad bhaviṣyati.
} 
En realidad, la búsqueda de legitimidad refleja y está atravesada por los profundos cambios que la sociedad india experimentó en los primeros siglos de la era común, cuando la tradición védica perdió el monopolio de la lengua sánscrita y ésta comenzó a servir de medio para experimentar con nuevos registros y dar voz a preocupaciones diferentes, en primera instancia gracias a la actividad de rapsodas y narradores (süta, kathaka) y más tarde a través de la invención de la literatura propiamente $(k \bar{a} v y a)$, transformando para siempre el uso del sánscrito de lengua litúrgica en lengua culta ${ }^{29}$. Al fin producto de su época, el relato sobre el origen del teatro en el primer libro del Nātyaśāstra no sólo revela estas tensiones sino que, consciente de ellas, las usa para lograr sus fines.

Es claro, pues, que el texto contiene elementos procedentes de distintos horizontes históricos y conceptuales, algunos más antiguos o arcaizantes que otros. A colación puede traerse el exordio que casi al final del texto pronuncia Brahmā tratando de convencer a los demonios de la naturaleza universal del teatro:

No hay saber ni destreza, ni ciencia ni arte, ni yoga ni oficio que no aparezca desplegado en el teatro. Todas las disciplinas, artes y oficios confluyen en esta mi creación [...] siendo yo su autor, recrea y pone en escena las peripecias de dioses, demonios, príncipes, jefes de familia, sacerdotes y profetas ${ }^{30}$.

Como apenas vimos, la secuencia concluye con la identificación entre teatro e itihāsa a la luz de un ideal lúdico, el principal objetivo de este nuevo arte. Así pues, casi sin querer y con pasos ligeros, en este largo y exaltado monólogo Brahmā acaba por relativizar la autoridad védica, así como la centralidad del fin didáctico erigido sobre el ritual.

Desde este ángulo, las nociones de veda y yajña, usadas comparativamente con el fin de establecer la grandeza del teatro ${ }^{31}$, si bien fungen como categorías que dotan de poder explicativo y legitimidad, no lo hacen para persuadirnos necesaria o exclusivamente del origen y la esencia védica del teatro. Por lo tanto, no parece incorrecto afirmar que la antigua dramaturgia sánscrita, al menos en esta lectura canónica de los primeros siglos de la era común, en vez de reducir la representación teatral a sacrificio (Byrski) o limitarse a reiterar el rito (Kuiper), en

${ }^{29}$ Al respecto véase Sh. Pollock, The Language of the Gods in the World of Men (Berkeley 2006), en especial la primera parte, "The Sanskrit Cosmopolis".

${ }^{30}$ 1.117-120: nāsau yogo na tatkarma nātye 'smin yan na dṛśyate | sarvaśāstrāṇi śilpāni karmāṇi vividhāni ca. asmin nātye sametāni tasmād etan mayā krtam ... yenānukaraṇam nātyam etat tad yan mayā kṛtam. devānām asurāṇām ca rājñ̄ām atha kuṭumbinām | brahmarșịnām ca vijñeyam nātyam vrttāntadarśakam.

${ }^{31}$ Respectivamente 1.4 y 1.128: vedasammita y yajñasammita. Como apunta Gitomer (op. cit. 179-180), el uso que el texto da a la noción de "sacrificio" (yajña) no es regular, pues la palabra es alternada con su equivalente post-védico, pūjā o “adoración”, mucho más próximo al hinduismo popular de los horizontes épico y purāṇico. 
realidad tiene su punto de partida en una doble preocupación apologética. Por un lado, reconoce y honra la autoridad brahmánica, en la que aspira encontrar justificación; por el otro, sin embargo, este mismo reconocimiento contiene un fuerte sentido de anticipación, rebasa el entorno propiamente védico en miras a algo más. Esa otra cosa, lo que está por acontecer, es desde luego la puesta en escena como tal, en lo que tiene de novedosa e inédita respecto al mito y rito originales.

Una primera forma de intentar explicar esta combinación de arcaísmo e innovación sería, como ha hecho L. Bansat-Boudon recogiendo el legado de Ch. Malamoud, apelar a la tendencia profundamente arraigada en la India de considerar todo nuevo comienzo como un momento particularmente crítico, expuesto a toda clase de peligros y que por lo mismo es necesario proteger. Piénsese, por ejemplo, en las acciones destinadas a proteger ritualmente el alumbramiento, un nuevo ciclo lunar o incluso la pronunciación de un mantra ${ }^{32}$. En todos estos casos, al evocar antigüedad, tradición y, por lo tanto, buena fortuna, el rito cumple la función de postergar o demorar el inicio de algo, aligerando el peso de lo nuevo e inédito, y conjurando así cualquier infortunio. Entonces, explica Bansat-Boudon, el ritual que precede a la puesta en escena -evento singular e imprevisible como cualquier expresión artística ${ }^{33}$ - constituiría por sí mismo un comienzo, pero uno propicio en virtud de sus antecedentes míticos y rituales fuera del escenario. De este modo, cuando Brahmā aconseja llevar al escenario el quinto Veda durante la fiesta que conmemora la victoria de Indra sobre el caos, y, luego, cuando el sabio Bharata elige como tema de su opera prima precisamente el combate entre dioses y demonios, ambas decisiones estarían buscando aliviar la inquietud que surge de enfrentarse con lo desconocido e inédito por medio de una reiteración de valores tradicionales ${ }^{34}$.

Todo esto puede ser cierto y nos ofrece un primer contexto para entender la doble retórica del Nätyaśāstra en torno a los orígenes del drama. Me parece, sin embargo, que tal planteamiento deja un poco de lado las implicaciones socioculturales detrás de la necesidad de ritualizar el teatro, no tanto ya en el afán de reconocer la autoridad védica sino porque se sabe que se está dando inicio a una aventura que, de manera implícita o no, posee cierto componente crítico contra una tradición que por siglos monopolizó el acceso al conocimiento restringiendo con celo el uso de la lengua sánscrita entre los diferentes estamentos de la

${ }^{32}$ En este último caso a través de la técnica de "envolver" o "rodear" (sampuțīkāra) fonéticamente los mantras. La misma se basa en un entendimiento del mantra como organismo vivo y, por lo tanto, sujeto a las impurezas del nacimiento y la muerte. Tales impurezas son evitadas "rodeando", "cubriendo" el mantra con otros mantras. Quizá el caso más conocido sea el gāyatrī védico (Rgveda 3.62.10), tradicionalmente "escoltado" (sampuțikrta) por la sílaba OṂ más las tres palabras sagradas (vyāhṛti) bhūr bhuvah svah. La literatura tántrica también ofrece varios ejemplos.

${ }^{33}$ Recordemos que de manera convencional los grandes dramaturgos reservan una línea o dos en el prólogo de sus obras para elogiar a su audiencia vinculando el buen gusto con la avidez por presenciar tramas novedosas (apürva), en lo que desde luego constituye una forma sutil de autoelogio.

${ }^{34}$ Bansat-Boudon, op. cit. 69-70. 
sociedad. Desde esta óptica diríamos entonces que el acto mismo de buscar legitimidad en la religión sacrificial védica representa una forma de emancipación. Para entender mejor a qué me refiero con esto conviene volver al tratamiento que recibe el mito de Indra y revisar el modo como éste transita desde su original horizonte religioso al propiamente escénico y, sobre todo, el efecto que este desdoblamiento tiene sobre ese nuevo depositario de las antiguas historias: el espectador, figura sin precedentes en la cultura védica.

\section{El UNIVERSO TEATRAL, UN UNIVERSO PARALELO}

Una lectura cuidadosa del núcleo de la historia en el primer libro del Nātyaśāstra, esto es, la descripción de la primera puesta en escena en el marco de la fiesta del estandarte de Indra y las secuelas de este evento fundacional, revela una diferencia esencial, sobre la que no siempre se repara, a saber, la que separa al mito-relato del mito-escena, a la memoria ritual del rito teatralizado.

El texto revela una clara conciencia de estos dos momentos o, más exactamente, sobre el hecho de que se trata de momentos distintos, de manera que el segundo de ellos, la representación dramática, a pesar de desplegar sobre el escenario los mismos sucesos, no por ello se reduce a una repetición o actualización del mito-relato. Como señala Gitomer, tanto la legendaria escaramuza cosmogónica como la ritualización que la actualiza cíclicamente aparecen ahora tematizadas como una alegoría de la representación teatra ${ }^{35}$. Jamás se asume que la continuidad del universo real dependa de esta reiteración sobre el escenario y, sin embargo, la misma adquiere, a su manera, proporciones cosmogónicas, pues crea un universo paralelo, tan meritorio como el universo real en virtud de sus cualidades estéticas. ¿Cómo lo sabemos? Por la reacción de los espectadores.

Dioses y demonios no sólo conocen el mito, su parte en él y el desenlace, sino que además lo conmemoran a través de una fiesta religiosa (y ya no sólo por medio de la actualización litúrgica formal). Sin embargo, el recuerdo festivo de la trama mítica no posee el efecto que produce su puesta en escena. Sólo esta última tiene el poder de convertir al espectador en actor, de lograr una identificación plena entre histriones y audiencia. Antes de que la historia sea llevada al escenario, el mundo sigue siendo el mismo y su curso permanece inalterado. El mundo deja de ser el mismo, sin embargo, cuando esa historia es transformada en arte. Inducidos por la magia que irradia el espectáculo, dioses y demonios reviven su añeja hostilidad y vuelven a luchar. Tan inesperada consecuencia propicia de hecho la institucionalización del quinto Veda a través de la erección de recintos (estrofas 78-98).

\footnotetext{
${ }^{35}$ Gitomer, op. cit. 186.
} 
Asemejarse (sammita) a los Vedas, repetir una historia consagrada o imitar este mundo de claroscuros -los tres grandes temas en torno al origen del drama en el primer capítulo del Nātyaśāstra-, no impiden que el Nātyaveda posea su propia fuerza creadora, abierta a lo inusitado; antes bien es a partir de tales motivos que deriva su riqueza expresiva y en última instancia su autonomía. En este sentido cabría decir que la experiencia estética, si así puede llamarse la reacción de los espectadores arquetípicos, dioses y demonios, no apunta pues a un escape del mundo, sino a una intensificación estética de ese único mundo ${ }^{36}$.

En suma, mientras que la actualización puramente ritual del mito-relato se limita a sostener el orden natural frente al caos, la reiteración escénica de esa misma historia, su mimesis, reconfigura la sensibilidad de la audiencia con la promesa de una mirada más intensa y plena a la realidad natural, mirada que al mismo tiempo y paradójicamente mantiene su resonancia védica. El teatro traslada el mito del ámbito puramente religioso al de la cultura; añade un valor estético al rito y ahí mismo inaugura un nuevo universo, afirma una identidad propia, aunque sin dejar de reconocer el legado de la tradición, de la que de algún modo sigue dependiendo. Es en este sentido limitado y sutil que, una vez más, lo que empieza como un reconocimiento de la superioridad védica acaba anunciando su subordinación. Aunque disfrazado retóricamente por las razones arriba expuestas, me parece que tal es el mensaje final de la peculiar apropiación que el primer libro del Nătyaśāstra hizo del tema del origen.

\section{Epílogo}

Como hemos visto, de acuerdo con el relato del Nātyaśāstra sobre el origen del teatro, dioses y demonios fueron los primeros espectadores. De manera tácita, esta historia enmarca los capítulos subsecuentes del texto hasta reaparecer expresamente en el último de ellos. Ahí nos enteramos que el don de ser espectador finalmente es concedido a los humanos, de modo que el quinto Veda desciende, por mediación de Bharata, al plano de los mortales. De esto se sigue que, al ser testigo del formidable espectáculo que el teatro despliega, el hombre tiene la posibilidad de estar, por un instante, en la situación de un dios. A la luz del análisis en las páginas anteriores, ello significaría ante todo estar en condiciones de saborear y revivir

${ }^{36}$ No es éste el espacio para ahondar en las implicaciones que tal conclusión posee sobre la teoría estética que el propio Nātyaśāstra desarrolla en sus libros sexto y séptimo, y la cual gira alrededor de la noción de rasa. Diré únicamente que al menos este primer capítulo parece respaldar la teoría estética más antigua que, vía Abhinavagupta, se ha conservado, a saber, la de Bhațtalollața (aprox. siglo VIII), quien defendió justamente que el rasa es la experiencia intensificada (upacita) de las emociones humanas básicas (sthāyībhāva) a partir de un manejo adecuado de diferentes factores escénicos (causales, consecuentes y concomitantes). Ahora bien, para Bhațtalollața -y a diferencia de Abhinavagupta-, semejante intensificación en realidad sólo tiene lugar en el escenario, sólo la vive el personaje imitado y el actor que lo imita, mientras que el espectador la reproduce o experimenta por un efecto ilusorio y no como algo real o propio. Véase Abhinavabhāratī ad Nātyaśāstra 6.2-9. 
intensamente tramas e historias bien conocidas, de dominio público, pero que una vez transformadas en drama adquieren un inesperado y casi hipnótico poder expresivo. Ese poder es tal que a pesar de ser ilusorias, de ser ficción, o justo por ello mismo, las representaciones teatrales logran evocar un sentido de realidad, tal como les sucedió a dioses y demonios. Desde luego son muchas las implicaciones de una conclusión así y algunas de ellas claramente rebasan el ámbito teatral para internarse en el de la reflexión estética y filosófica en general ${ }^{37}$.

Digamos apenas, a manera de epílogo, que la retórica de doble filo que recorre los versos del primer libro del Nătyaśāstra y a la que este artículo ha prestado particular atención, parece culminar precisamente en un juicio positivo de la realidad teatral por mor de su irresistible naturaleza ilusoria.

Esta antigua y sutil apología del teatro acabaría siendo afirmada por la teoría literaria sánscrita que, sin tapujos, declaró que el teatro es la forma más elevada de literatura $(k \bar{a} v y a)^{38}$, un arte completo que al mismo tiempo seduce el oído y la vista $^{39}$, envolviendo a la audiencia con su encanto y suntuosidad multidisciplinaria, con su despliegue de recursos técnicos y artísticos - punto de encuentro de gestualidad, voz, danza, maquillaje, música, decoración y una larga lista de etcéteras-, hasta desencadenar en ese mismo espectador la sensación de que no hay prodigio más grande que la ilusión misma. Al permitirnos ver la naturaleza ilusoria de este mundo, al permitir deleitarnos en ella, por un instante el teatro nos permite escapar a la ilusión, ser libres, tal como los dioses son libres respecto a su asombrosa creación, libertad que les permite contemplarla y, al hacerlo, experimentar placer.

\footnotetext{
${ }^{37}$ No en vano el teatro es una de las metáforas favoritas de la metafísica india y su penetrante análisis del fenómeno de la ilusión versus lo real. Al respecto vienen a la mente los casos del sāṃkhya y el shivaísmo de Cachemira.

${ }^{38}$ A manera de ejemplo pueden recordarse las palabras, entre otros, de Vāmana en su $K \bar{a}$ vyālaṃkārasūtra (1.3.30-32): "De todas las composiciones literarias, la mejor es el teatro". Citado en Bansat-Boudon, op. cit. 21, n. 2.

${ }^{39}$ Como pide Indra a Brahmā (estrofa 11cd).
} 